\title{
IGF-I/IGFBPs system response to endotoxin challenge in sheep
}

\author{
N Briard ${ }^{1}$, F Dadoun ${ }^{1,2}$, G Pommier ${ }^{3}$, N Sauze ${ }^{1}$, Y Lebouc $^{4}$, \\ C Oliver ${ }^{1,2}$ and A Dutour ${ }^{1,2}$
}

${ }^{1}$ Laboratoire de Neuroendocrinologie Experimentale, INSERM U501, Institut Fédératif Jean Roche, Bd P. Dramard 13916 Marseille Cedex 20 , France

${ }^{2}$ Service d'Endocrinologie, Maladies Métaboliques et de la Nutrition, Hôpital Nord, Chemin des Bourrely 13915 Marseille Cedex 20 , France

${ }^{3}$ Unité interactions protéiques et différenciation de la cellule tumorale, ESA CNRS 6032, 27 bd Jean Moulin, 13385 Marseille, France

${ }^{4}$ Explorations fonctionnelles en Endocrinologie, Hôpital Trousseau, AP-HP, 75571 Paris Cedex 12, France

(Requests for offprints should be addressed to A Dutour, Service d'Endocrinologie, Maladies Métaboliques et de la Nutrition, Hôpital Nord, Chemin des Bourrely, F-13915 Marseille Cedex 20, France)

\begin{abstract}
Endotoxin (LPS), a membrane component of gramnegative bacteria produces multiple endocrine and metabolic effects that mimic those seen in acute sepsis. It induces species-dependent alterations of the growth hormone $(\mathrm{GH})$ axis that may participate in the shift of the metabolism towards catabolic events. Humans and sheep show increased GH secretion in response to LPS, as opposed to rats, which have been the most studied. The purpose of our work was to evaluate the effects in intact rams of an acute intravenous administration of a high dose of LPS on the insulin-like growth factor (IGF)-I/IGFbinding proteins (IGFBPs) system and to analyse the temporal relationship of $\mathrm{GH}$ axis changes with those of several hormonal and metabolic parameters such as somatostatin, cortisol, insulin, and glucose.

LPS induced a late moderate decrease of total IGF-I plasma levels following a $5-\mathrm{h}$ steady-state period $(-26 \cdot 6 \pm 4 \cdot 2 \%, P<0 \cdot 05,9 \mathrm{~h}$ after LPS), despite a biphasic and sustained increase of $\mathrm{GH}$ secretion in the same animals $(2.48 \pm 0.39 \mathrm{ng} / \mathrm{ml} 2 \mathrm{~h}$ after LPS and $2.7 \pm 0.37 \mathrm{ng} / \mathrm{ml}$ $5 \mathrm{~h}$ after LPS vs $0.77 \pm 0.10$ before LPS; Briard et al. 1998a). Western ligand blot analysis in IGFBPs showed an
\end{abstract}

early short-lasting increase in IGFBP-1 (188.8 $\pm 39 \%$ $P<0 \cdot 05,3 \mathrm{~h}$ after LPS). No significant change was seen for either IGFBP-2, -3 or -4 . We observed a marked and sustained increase in cortisol $(128 \cdot 18 \pm 7 \cdot 21 \mathrm{ng} / \mathrm{ml} 3 \mathrm{~h}$ after LPS, vs $21 \cdot 17 \pm 4 \cdot 22$ before LPS). Insulin also increased $(27.69 \pm 3.90 \mu \mathrm{U} / \mathrm{ml} \quad 3 \mathrm{~h}$ after LPS, vs $13.48 \pm 1.69$ before LPS) and its burst coincided with that of IGFBP-1.

Moderately decreased IGF-I and increased IGFBP-1 plasma levels contrasted with the sustained increase in $\mathrm{GH}$ secretion that we recently described, thereby suggesting that endotoxin causes a state of resistance to GH. This may be exacerbated by reduced IGF-I bioavailability and/or action, and which may participate in the pathophysiology of the catabolic state seen in sepsis. The temporal analysis of hormone responses suggests that endotoxin-induced alterations of the IGF-I/IGFBPs system may involve the prolonged and substantial somatostatin rise that we recently demonstrated, together with an increase in glucocorticoid and cytokine as more generally assumed. Journal of Endocrinology (2000) 164, 361-369

\section{Introduction}

The interaction of the immune and neuroendocrine systems has recently been a matter of great interest. Septic shock, endotoxemia and sepsis as well as critical illness and inflammation are associated with complex hormonal changes that might affect both the immune and metabolic responses and contribute to a damaging catabolic state with weight loss, abnormal glucose regulation and severe muscle proteolysis (Mizock 1995, Cooney et al. 1997, Chang \& Bistrian 1998). Among the endocrine effects of sepsis, incompletely characterised alterations in the somatotroph axis have been demonstrated that may contribute to hypercatabolism (Voerman et al. 1992, Botfield et al.
1997). Endotoxin (LPS), a lipopolysaccharide found as a principal component of gram-negative bacteria, is the main mediator of septic shock (Morrison \& Ryan 1987). It has been shown to be a potent stimulator of the immune system as well as a modulator of several mediators and hormones. Schematically, LPS administration induces a rapid increase in plasma concentration of tumour necrosis factor alpha (TNF- $\alpha$ ), interleukin (IL)-1 and IL-6. In turn, endotoxin, together with circulating cytokines, stimulates eicosanoid and interleukin production by various tissues including the hypothalamus and the pituitary (Tilders et al. 1994). LPS induces multiple endocrine and metabolic effects that mimic those seen in acute sepsis (Jenkins \& Ross 1996a, Van den Berghe et al. 1998). It increases 
activity of the hypothalamic-pituitary-adrenal (HPA) axis (Makara et al. 1971, Rivier et al. 1989, Tilders et al. 1994, Dadoun et al. 1997) and decreases thyrotrophin (TSH) (Elson et al. 1982) and luteinizing hormone (LH) (Peter et al. 1989, Battaglia et al. 1997) secretion.

Endotoxin effects upon GH-axis are species-dependent. In rats, the whole $\mathrm{GH}$-axis is depressed: $\mathrm{GH}$ secretion and IGF-I plasma concentration are decreased after endotoxin challenge (Kasting \& Martin 1982, Fan et al. 1994, Soto et al. 1998). Conversely, GH secretion is increased after endotoxin challenge in humans (Elin et al. 1981), pigs (Hevener et al. 1997) and sheep (Coleman et al. 1993). We recently confirmed these data in sheep and demonstrated the pituitary as the main site for LPS effect upon GH secretion (Briard et al. 1998a). In humans (Lang et al. 1997) and pigs (Hevener et al. 1997), total plasma IGF-I is nevertheless decreased. LPS effect upon IGF-I has not yet been characterised in sheep. This parameter demonstrates major functional significance since decreases in plasma IGF-I are strongly correlated with imbalanced nitrogen status and hypercatabolism (Cohick \& Clemmons 1993, Donaghy \& Baxter 1996). Moreover a number of studies suggest that IGF-I treatment may assist recovery from catabolic states related to sepsis (Jurasinski \& Vary 1995, Balteskard et al. 1998).

Furthermore, LPS might alter IGF-I action through changes in circulating IGF binding proteins (IGFBPs) as demonstrated in several species: increased IGFBP-1, -2 and/or -3 in rats (Fan et al. 1994, Soto et al. 1998), decreased IGFBP-2 in cattle (Elsasser et al. 1995) and increased IGFBP-1 in humans (Lang et al. 1997). Although hypercatabolism seen in sepsis is certainly multifactorial, IGF-I decrease, and alterations of its bioavailability and/or actions through IGFBPs modulations, could be involved. The mechanism(s) leading to these alterations in the IGF-I/IGFBPs system remain(s) unclear.

Because of similarities between humans and sheep in LPS action, i.e. catabolic state contrasting with increased GH secretion, sheep appear to be an interesting model on which to assess the effect of acute LPS on the IGFI/IGFBPs system, yet uncharacterised in this species. Indeed, high doses of endotoxin that lead to clinical features seen in severe sepsis cannot be used on humans for ethical reasons. Sheep, being a ruminant, are also an interesting model since large nutrient reserves in the rumen may limit the specific impact of endotoxin-induced anorexia (Elsasser et al. 1995) and, therefore, may dissociate indirect nutritional effects from more direct endotoxin effects.

We previously treated sheep with a high dose of endotoxin in order to determine the effect of this compound upon GH secretion (Briard et al. 1998a). The purpose of the current work was to evaluate the concomitant effect of endotoxin on the IGF-I/IGFBPs system in the same animals, and to analyse the temporal relationship of these changes with those of several hormonal and metabolic parameters that might affect $\mathrm{GH}$-axis regulation, such as somatostatin, cortisol, insulin, and glucose.

\section{Materials and Methods}

\section{Animals}

Four intact rams (9-11 months old, 40-45 kg body weight) from the Merino Alps breed were obtained from ENSA (Domaine du Merle, Salon de Provence, France). Two weeks prior to the onset of the study, rams were transferred to the animal room of the laboratory. All experimental procedures were performed in accordance with local animal-use regulations. Studies were approved by the Faculty Committee on the Use and Care of Animals.

\section{Experimental procedure}

The animals $(n=4)$ were housed in individual pens placed immediately adjacent to each other. They were free to sit or to stand and exposed to natural lighting conditions. The day preceding the experiment, an indwelling catheter was inserted into the external jugular vein. On the following day, endotoxin was administered by an i.v. bolus injection $(200 \mathrm{ng} / \mathrm{kg}$ ) in $2 \mathrm{ml}$ saline through the jugular cannula, followed by $5 \mathrm{ml}$ saline as previously described (Coleman et al. 1993, Briard et al. 1998a). Endotoxin (Escherichia coli 055: B5: Sigma, St Louis, MO, USA) was diluted in phosphate-buffered saline with $0 \cdot 1 \%$ bovine serum albumin to a stock concentration of $0 \cdot 1 \mu \mathrm{g} / \mu \mathrm{l}$. Anticoagulation was achieved using heparin (bolus of 25000 IU at the beginning of the sampling period, followed by infusion of $10000 \mathrm{IU} / \mathrm{h}$ ).

Body temperature and general welfare of the animals was evaluated regularly. Jugular blood was collected every 15 min during the $2 \mathrm{~h}$ period preceding endotoxin injection and during the subsequent $9 \mathrm{~h}$. Blood samples were collected in chilled tubes and immediately centrifuged at $4{ }^{\circ} \mathrm{C}$ for $10 \mathrm{~min}$. The resulting plasma was stored at $-20{ }^{\circ} \mathrm{C}$ until assayed for IGF-I, IGFBPs, cortisol, insulin, and glucose.

\section{Hormone and glucose assays}

All assays were performed in plasma samples previously used for $\mathrm{GH}$ and somatostatin radioimmunoassay, the results of which have been reported in Briard et al. $1998 a$.

Total plasma IGF-I was measured using a wellestablished assay system (Hardouin et al. 1989) previously validated in sheep (Briard et al. 1998b). Briefly, samples were gel filtered in acetic acid on columns of Ultrogel AcA54 (Sepracor/IBF s.a., Villeneuve la Garenne, France) 
in order to separate IGFs from their binding proteins. Recombinant human IGF-I was provided by Ciba-Geigy Ltd (Basel, Swizerland) and was used as cold standard and radioactive tracer after iodination by the chloramine- $\mathrm{T}$ method. IGF-I RIA was performed using anti-IGF-I antiserum prepared by Dr Closset (Liège, Belgium). Unknown samples were studied at three concentrations, each in duplicate plus one non-specific binding tube. Intra- and inter-assay coefficients of variation were 4.8 and $10 \%$ respectively. Because of disparities in individual IGF-I basal (pre-endotoxin) plasma levels, IGF-I was expressed as a percentage of mean basal plasma value.

IGFBPs serum profile was evaluated using Western ligand blotting as previously described (Hossenlopp et al. 1986, Baciuchka et al. 1998). Non reduced samples were submitted to SDS-PAGE on $12 \cdot 5 \%$ polyacrylamide slab gels before electrotransfer onto nitrocellulose. Nitrocellulose membranes were probed with approximately $2.5 \times 10^{5}$ c.p.m. $/ \mathrm{ml}\left[{ }^{125} \mathrm{I}\right]-\mathrm{IGF}-\mathrm{II}$ (Amersham, Aylesbury, UK) and IGFBPs visualised by autoradiography. Autoradiographic films were quantified by densitometric scanning (Sharp JX-325 laser densitometer, Pharmacia Biotech., St Quentin en Yuelines, France) followed by computerised image analysis (Image Master Software; Pharmacia Biotech., St Quentin en Yvelines, France). Densitometric analyses were performed on films with different exposure times and those that gave linear signal curves were used for semiquantitative analysis. For each band, the signal level was expressed as a percentage of each animal value measured at time 0 .

Cortisol was measured in plasma extracts according to a previously described RIA method (Dadoun et al. 1997). The limit of detection and the intra-assay coefficient of variations were $0.5 \mathrm{ng} / \mathrm{ml}$ and $4.7 \%$ respectively.

Insulin was measured using a commercially available radioimmunoassay kit (INSI-PR, Cis bio international ORIS, Gif-sur-Yuette, France) previously validated in sheep (Bocquier et al. 1998); assay sensitivity was $3.6 \mu \mathrm{U} /$ $\mathrm{ml}$; intra-assay and inter-assay coefficients of variations were respectively $6 \%$ and $5 \cdot 3 \%$.

Plasma glucose was measured by the glucose oxidaseperoxidase method, using a commercially available kit (Glucose enzymatique color liquide, Biotrol Merck diagnostic, Nogent sur Marne, France).

\section{Statistical analysis}

All data are reported as mean \pm s.E.M. Mean plasma IGF-I, IGFBP-1, cortisol, insulin and glucose values were calculated during each hourly period of sampling. Paired Student's $t$-tests were used in all statistical analyses between hourly periods (designated H-2 to H9), using a computer software program (Statview 512, Brain Power, Inc, Calabasas, CA, USA). For IGF-I and IGFBP-1, additional statistical analyses were performed between different sampling times using paired Student's $t$-test, since only one measurement was performed in hourly period $\mathrm{H} 5$ and H9. $P<0 \cdot 05$ was considered significant.

\section{Results}

Intravenous administration of $200 \mathrm{ng} / \mathrm{kg}$ endotoxin led to increased respiration, intermittent coughing and diarrhoea, and a lack of alertness to the surroundings. High body temperature $\left(41-43^{\circ} \mathrm{C}\right)$ was recorded in all animals and lasted for $6 \mathrm{~h}$.

\section{IGF-I/IGFBPS}

During the $5 \mathrm{~h}$ period following endotoxin injection (H1 to H5), IGF-I plasma levels remained unchanged $(P>0 \cdot 2)$; a subsequent moderate but significant decrease of IGF-I was seen during $\mathrm{H} 9$ (H9: $73.4 \pm 4.2 \%, P<0.05$ vs $\mathrm{H}-1$, $\mathrm{H}-2)$ and each pre-endotoxin sampling time.

IGFBPs plasma profile consisted of five major bands that included a doublet of 39-41 kDa, and three smaller bands of approximately 34,30 , and $24 \mathrm{kDa}$ (Fig. 1). It conforms to that described in human (Hardouin et al. 1989) and cow (Cohick et al. 1992) plasma using both ligand blotting and immunoblotting techniques, and matches with that previously described in sheep using a ligand blotting technique comparable to ours (McCann et al. 1997). The nomenclature derived from these studies was applied to our results and IGFBPs of 24, 30, 34 and 39-41 kDa were designated IGFBP-4, $-1,-2$ and -3 respectively. IGFBP-1 increased later than $\mathrm{GH}$, approximately $105 \mathrm{~min}$ after endotoxin injection, remained significantly elevated until $\mathrm{H} 4$ and then decreased (H-1: $105 \cdot 1 \pm 6 \cdot 3 \%$; H3: $188 \cdot 8 \pm 39 \cdot 0 \%, P<0 \cdot 05$ vs $\mathrm{H}-1$ and $\mathrm{H}-2 ; \mathrm{H} 4: 183 \cdot 6 \pm$ $40 \cdot 2 \%, P<0 \cdot 05$ vs $\mathrm{H}-1, \mathrm{H}-2$ and each pre-endotoxin sampling time) (Figs 2 and 3 ). No significant change was seen for either IGFBP-2, -3 or -4 after endotoxin challenge.

In a previous study, approximately 75 min after the endotoxin injection, we observed in the same animals, a significant increase in plasma GH levels $(\mathrm{H}-1$ : $0 \cdot 77 \pm 0 \cdot 10 \mathrm{ng} / \mathrm{ml} ; \mathrm{H} 2: 2 \cdot 48 \pm 0 \cdot 39 \mathrm{ng} / \mathrm{ml}, P<0 \cdot 0005$ vs H-1 and H-2) (Briard et al. 1998a). A second and major sustained increase in $\mathrm{GH}$ concentration was observed during the fifth hourly period after endotoxin administration (H5: $2 \cdot 7 \pm 0 \cdot 37 \mathrm{ng} / \mathrm{ml}, P<0 \cdot 0005$ vs $\mathrm{H}-1$ and $\mathrm{H}-2)$ and lasted until the end of the sampling period.

\section{Other parameters}

The HPA axis was rapidly and very strongly activated (Figs 2 and 3). Cortisol rise occurred earlier and was much more substantial than that of GH (H-1: $21 \cdot 17 \pm 4 \cdot 22 \mathrm{ng} /$ $\mathrm{ml}$; $\mathrm{H} 1: 57 \cdot 83 \pm 12.56 \mathrm{ng} / \mathrm{ml}, P<0 \cdot 005$ vs $\mathrm{H}-1$ and $\mathrm{H}-2$; peak value during $\mathrm{H} 3: 128 \cdot 18 \pm 7 \cdot 21 \mathrm{ng} / \mathrm{ml}, P<0 \cdot 0005$ vs $\mathrm{H}-1$ and $\mathrm{H}-2)$. Cortisol levels remained significantly 


\section{Molecular \\ weight}

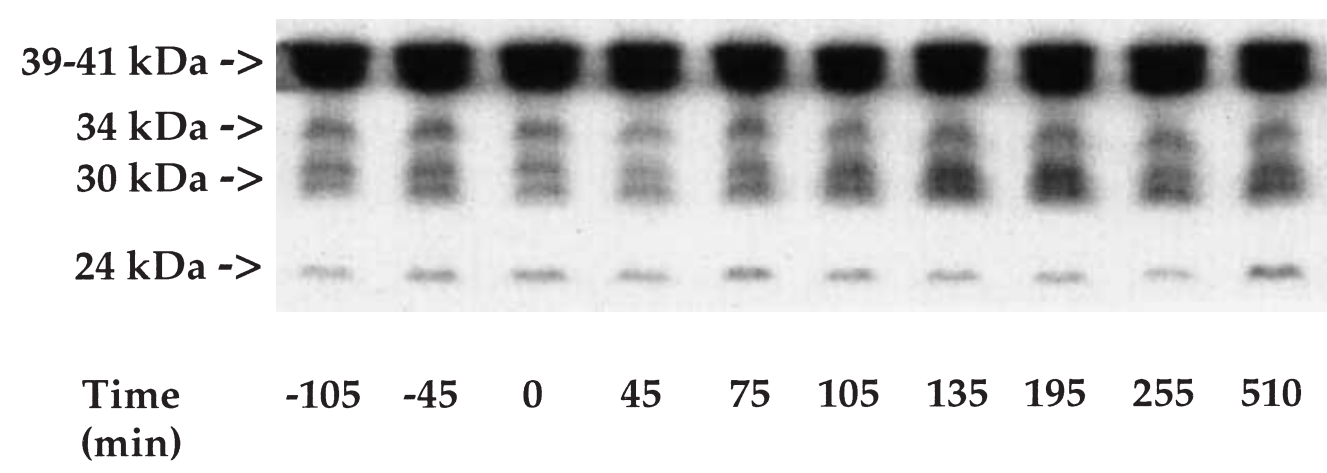

Figure 1 Western ligand blot analysis (WLB) of IGFBPs in plasma from one representative animal before ( $-105 \mathrm{~min},-45 \mathrm{~min}$ and 0 ) and after (45 min to $510 \mathrm{~min}$ ) an i.v. injection of endotoxin. Serum samples were submitted to WLB as described in Materials and Methods. IGFBPs were probed with [ $\left.{ }^{125} \mathrm{I}\right]-$ IGF-II and visualised by autoradiography. Molecular weights are shown on the left.

increased until the end of the sampling period $(P<0 \cdot 0005$ for each hourly period vs $\mathrm{H}-1$ and $\mathrm{H}-2$ ).

Glucose changes occurred later, leading to hypoglycaemia from $240 \mathrm{~min}$ until the end of the sampling period (H-1: $0.912 \pm 0.025 \mathrm{~g} / \mathrm{l} ; \mathrm{H} 4: 0.767 \pm 0.026 \mathrm{~g} /$, $P<0.0005$ vs $\mathrm{H}-1$ and $\mathrm{H}-2 ; \mathrm{H} 9 \quad 0.580 \pm 0.023 \mathrm{~g} / 1$, $P<0 \cdot 0005$ vs $\mathrm{H}-1$ and $\mathrm{H}-2$ ) (Figs 2 and 3 ).

Plasma insulin showed a significant rise starting at $120 \mathrm{~min}$ and lasting for $2 \mathrm{~h}(\mathrm{H}-1: 13.48 \pm 1.69 \mu \mathrm{U} / \mathrm{ml}$; H3: $27.69 \pm 3.9 \mu \mathrm{U} / \mathrm{ml}, P<0 \cdot 05$ vs $\mathrm{H}-1$ and $\mathrm{H}-2$; $\mathrm{H} 4$ : $28 \cdot 29 \pm 3 \cdot 42 \mu \mathrm{U} / \mathrm{ml}, P<0 \cdot 005$ vs $\mathrm{H}-1$ and $\mathrm{H}-2)$; this rise preceded the drop of glucose levels. Insulin levels then returned to baseline but remained high towards glycaemia (Figs 2 and 3).

In a previous study (Briard et al. 1998a), approximately 45 min after the endotoxin injection, we observed in the same animals a marked increase in somatostatin (SRIH) levels, culminating during $\mathrm{H} 2(\mathrm{H}-1: 11.62 \pm 1 \cdot 19 \mathrm{pg} / \mathrm{ml}$; $\mathrm{H} 2: \quad 66 \cdot 9 \pm 9 \cdot 75 \mathrm{pg} / \mathrm{ml}, \quad P<0 \cdot 0005$ vs $\mathrm{H}-1$ and $\mathrm{H}-2)$ (Briard et al. 1998a). This increase in peripheral plasma SRIH slightly preceded $(15 \mathrm{~min})$ the first GH rise. SRIH levels slowly returned to baseline (H4 to H6). A second sustained increase in SRIH levels was seen from $\mathrm{H} 7$ to H9 (H7: $33 \cdot 00 \pm 5 \cdot 12 \mathrm{pg} / \mathrm{ml}, P<0 \cdot 0005$ vs $\mathrm{H}-1$ and $\mathrm{H}-2$; H9: $34.94 \pm 4.36 \mathrm{pg} / \mathrm{ml}, P<0.0005$ vs $\mathrm{H}-1$ and $\mathrm{H}-2)$.

\section{Discussion}

As previously reported in the same species (Coleman et al. 1993), and also recently demonstrated in the animals used in the current study (Briard et al. 1998a), acute endotoxin administration evokes a sustained biphasic increase of $\mathrm{GH}$ release. A strong stimulation of the HPA axis occurred, together with the activation of the somatotroph axis as previously observed in intact rams using a higher dose of LPS (Dadoun et al. 1997) and in other species (Makara et al. 1971, Rivier et al. 1989, Tilders et al. 1994). Interestingly, we demonstrate here that a late decrease in IGF-I plasma levels, following a $5 \mathrm{~h}$ steady-state period, and an early short-lasting increase in IGFBP-1, contrast with the increase of $\mathrm{GH}$ secretion.

A similar dissociation between GH and IGF-I responses to endotoxin has been recently demonstrated in pigs (Hevener et al. 1997), and interestingly also in humans (Lang et al. 1997). In rats (Fan et al. 1994, 1995a) and cattle (Elsasser et al. 1995), reduced GH levels may at least partly explain IGF-I decrease. Conversely the IGF-I decrease observed in sheep suggests that endotoxin causes a state of resistance to increased $\mathrm{GH}$ in humans and pigs, as previously proposed by others (Hevener et al. 1997, Lang et al. 1997). Such a hypothesis concords with the low effectiveness of GH therapy to restore IGF-I levels and to reverse the catabolic state in septic patients (Gottardis et al. 1991, Dahn et al. 1998). Moreover, GH-resistance is welldocumented in cases of critical illness and catabolic states of diverse origins (reviewed in Jenkins \& Ross $1996 b$ and Donaghy \& Baxter 1996).

Furthermore, our results showed increased IGFBP-1 plasma concentrations that nearly doubled 3 to $4 \mathrm{~h}$ after endotoxin injection. Indeed, we cannot eliminate the possibility that IGFBP-3 proteolytic fragments and/or $\mathrm{N}$-glycosylated IGFBP-4 might migrate with the same mobility as IGFBP-1 using SDS-PAGE electrophoresis; however, these proteolytic fragments show much reduced affinity for IGF-II and are poorly detected by Western ligand blot (Lassarre \& Binoux 1994). Endotoxin has 

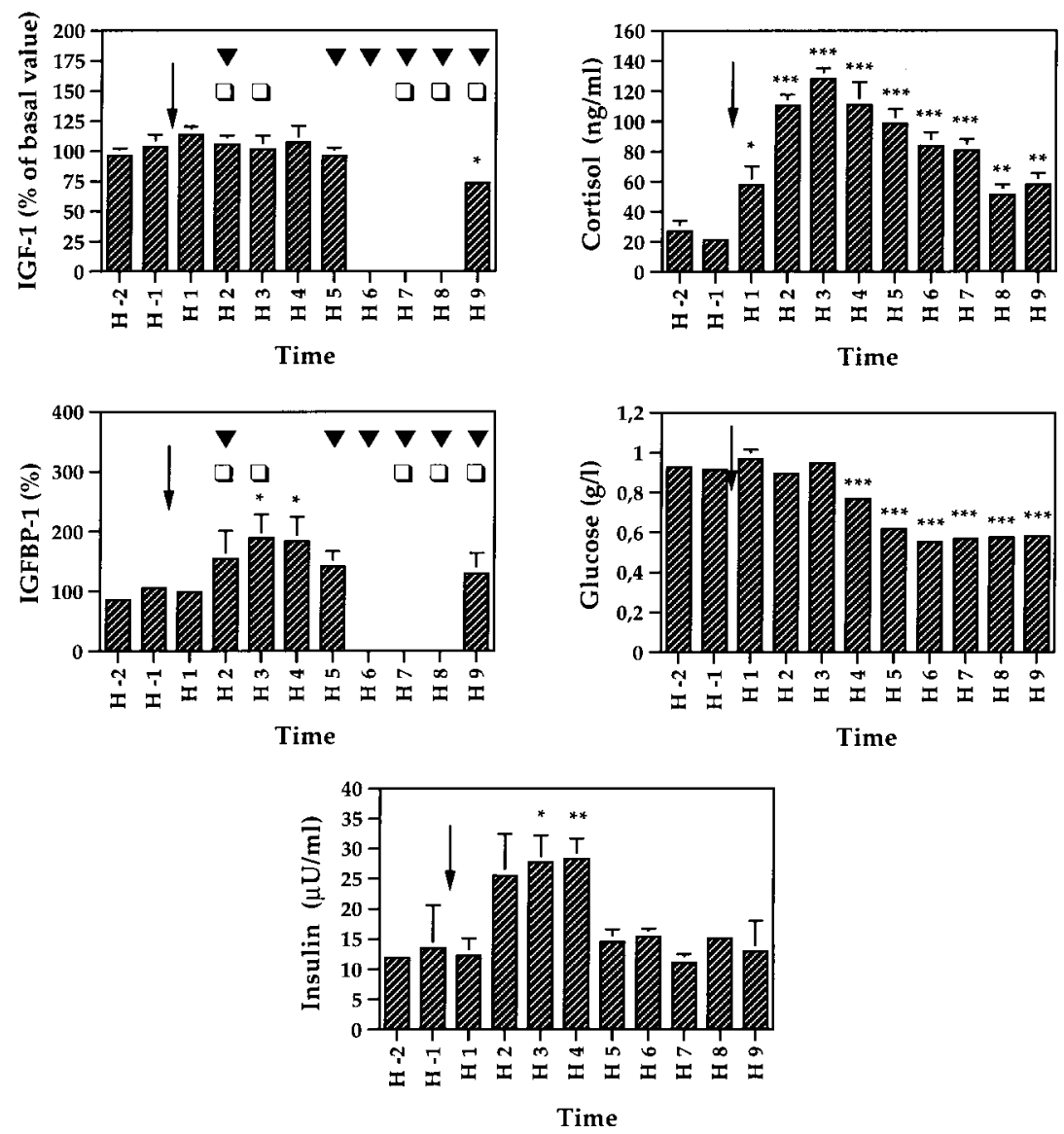

Figure 2 Effect of an i.v. injection of endotoxin (200 ng/ $/ \mathrm{kg}$; injection indicated by an arrow) on mean ( \pm S.E.M.) hourly IGF-I, IGF-BP1, cortisol, glucose and insulin plasma levels. Statistical significance vs basal values (both $\mathrm{H}-2$ and $\mathrm{H}-1$ hourly periods analysed separately): ${ }^{*} P<0 \cdot 05,{ }^{* *} P<0 \cdot 005,{ }^{* * *} P<0 \cdot 0005$. $\boldsymbol{\nabla}$, Hourly periods when plasma GH has been shown to be significantly increased in the same animals $(P$ at least $<0.005$ vs basal values; Briard et al. 1998a). $\square$, Hourly periods when plasma somatostatin has been shown to be significantly increased in the same animals $(P<0.0005$ vs basal values; Briard et al. 1998a).

previously been shown to modulate plasma IGFBPs. The increase in IGFBP-1 we observed in sheep shows similarities with data obtained in humans injected with small doses of LPS (Lang et al. 1997). In rats, in which GH plasma levels are suppressed by endotoxin, plasma IGFBP-1 changes match those seen in sheep (Fan et al. 1994, Soto et al. 1998).

The endotoxin-induced IGFBP-1 increase we observed in sheep may alter the peripheral response to changes in GH/IGF-I levels, through modulation of IGF-I bioavailability and/or action (Lee et al. 1993, Jones \& Clemmons 1995). IGFBP-I has been shown to inhibit IGF actions by binding to IGFs and preventing the binding of IGFs to IGF receptors, and especially to block the availability of IGFs for insulin-like actions (Lee et al. 1993, Lewitt 1994). Despite increased GH secretion, and initially preserved IGF-I levels, the early IGFBP-1 rise we observed may participate in protein breakdown through reduced IGF-I bioavailability, as more generally assumed in catabolic states (Brismar et al. 1994, Donaghy \& Baxter 1996, Jenkins \& Ross 1996b). Raised GH levels, together with reduced IGF-I action, may also favour direct GH metabolic effects, such as resistance to insulin, neoglucogenesis and lipolysis. These effects are typical features of septic states (Mizock 1995), and participate in the increased substrate disposal for vital organs such as the brain and the immune system which do not require insulin action for glucose transport (Van de Berghe et al. 1998). This may also partly explain the delayed hypoglycaemia we observed, which appeared once IGFBP-1 decreased. Indeed, decreasing IGFBP-1 may favour IGF-I insulin-like actions leading to hypoglycaemia because of increased glucose utilisation (Lee et al. 1993, Lewitt 1994). 


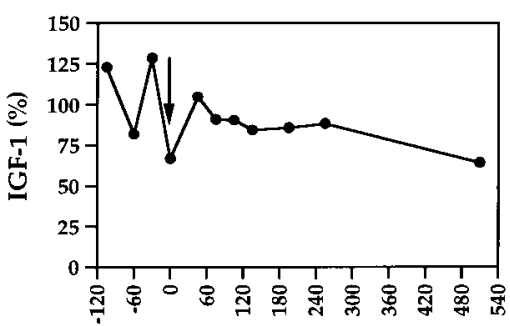

Time (min)

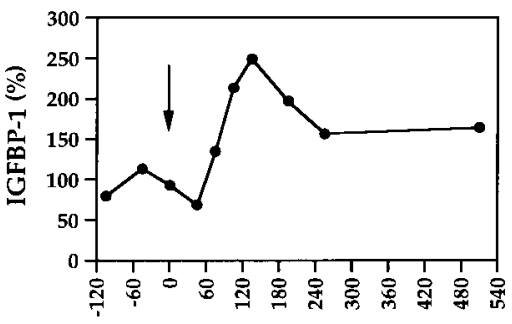

Time (min)

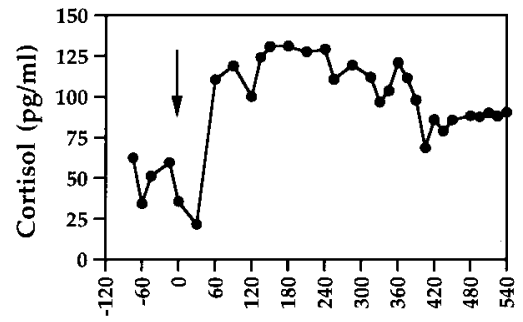

Time (min)

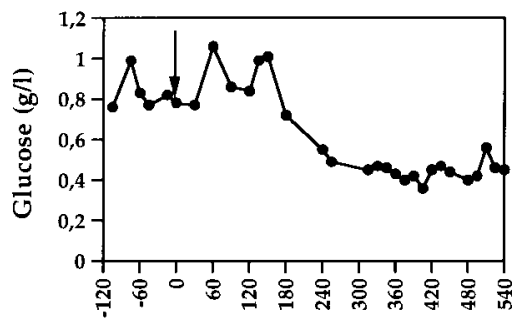

Time (min)

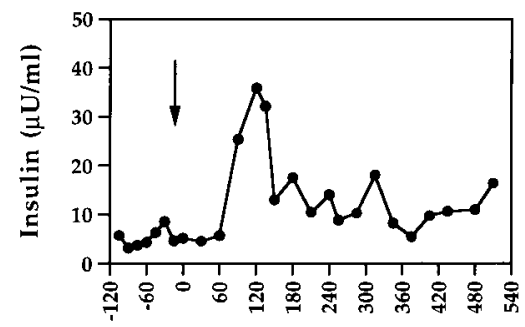

Time (min)

Figure 3 Effect of an i.v. injection of endotoxin ( $200 \mathrm{ng} / \mathrm{kg}$; injection indicated by an arrow), in one representative animal, on IGF-I, IGFBP-1, cortisol, glucose and insulin plasma levels.

Another consequence of IGFBP-I rise and altered IGF-I bioavailability may be reduced feedback of IGF-I upon $\mathrm{GH}$; this may explain at least in part the second increase in GH plasma concentration that we recently described in the same animals $4 \mathrm{~h}$ after endotoxin administration (Briard et al. 1998a), which shortly followed IGFBP-I zenith. The late decrease in IGF-I may also participate in sustaining this second GH rise. In sheep, IGF-I exerts its feedback action mainly at the pituitary level (Spencer et al. 1993, Fletcher et al. 1995). Indeed, we previously demonstrated that the second GH increase was not related to changes in GH RH and/or SRIH levels in hypothalamo-hypophysio-portal blood (Briard et al. 1998a).

Cytokines secreted in response to endotoxin such as TNF- $\alpha$, IL-1 $\beta$ and IL-6, may directly participate in the modulation of the IGF system. In vivo administration of TNF- $\alpha$ or IL- $1 \beta$ decreases IGF-I plasma levels and hepatic mRNA and show opposite effects upon IGFBP-1 in rodents (Fan et al. 1995b, 1996, Samstein et al. 1996). Similar effects in vitro suggest a direct hepatic mechanism
(Samstein et al. 1996, Thissen \& Verniers 1997). However multiple other factors may be involved and the temporal analysis of metabolic and hormonal changes facing the endotoxin-induced variations in IGF-I and IGFBP-1 may provide clues in understanding the mechanism(s) of these variations. Among potential regulatory factors, nutrition and insulin appear to be major regulators of IGF-I and IGFBP-1 (Lee et al. 1993, Jones \& Clemmons 1995). Decreased nutrient intake leads to GH-resistance, decreased IGF-I and increased IGFBP-1 plasma levels (Lee et al. 1993, Thissen et al. 1994, Donaghy \& Baxter 1996) and endotoxin-induced anorexia may participate in the IGF system changes we observed. However, in sheep, large nutrient reserves in the rumen may limit the specific impact of anorexia (Elsasser et al. 1995). This may also explain why in sheep IGF-I decrease was moderate and delayed, when compared with that seen in humans (Lang et al. 1997). In addition, decrease in glycaemia occurred after IGFBP-1. Therefore IGFBP-1 increase may not be ascribed to plasma glucose changes. 
An inverse relationship between IGFBP-1 and insulin has been demonstrated in most physiological and pathological conditions (Lee et al. 1993, Thissen et al. 1994, Jones \& Clemmons 1995). Interestingly, this inverse relationship is lacking in our model and changes in plasma insulin cannot account for those of IGFBP-1, since the rise in IGFBP-1 coincided with increased insulin levels. Insulin resistance has been demonstrated in endotoxemia and septic states (Mizock 1995) and may account at least in part for this loss of association between insulin and IGFBP-1 (Lee et al. 1993). Similarly the insulin changes we observed do not suggest involvement of insulin in IGF-I response to endotoxin, since insulin has been shown to increase IGF-I secretion both in vivo and in vitro (Pao et al. 1993, Brismar et al. 1994).

The IGF-I and IGFBP-1 changes we observed after endotoxin could be mediated by changes in other regulatory hormones such as glucocorticoids and somatostatin. In sheep, endotoxin-induced IGFBP-1 rise was preceded by an important burst of cortisol, and IGFBP-1 later decreased along with cortisol. Furthermore, the late IGF-I decrease we observed may be related to a suppressive effect of the prolonged cortisol rise. Indeed, glucocorticoid administration decreases hepatic IGF-I mRNA and increases IGFBP-1 gene expression leading to an important rise in the circulating levels of IGFBP-1 in both rats and humans (Luo et al. 1990, Conover et al. 1993). However, it has been proposed recently that in rats, endotoxin-induced IGFBP-1 increase is independent of glucocorticoids, as opposed to IGF-I changes, because of the differential effects of the glucocorticoid receptor antagonist RU-486 (Li et al. 1997).

SRIH involvement in IGF system modulation has received much less attention and its participation in endotoxin-induced effects has not been investigated. Interestingly, the increase in IGFBP-1 we describe here coincided or just followed the considerable increase in SRIH plasma concentration that we recently showed in the same animals (Briard et al. 1998a). This early rise in peripheral SRIH probably contributed to the increase in IGFBP-1. In vivo, octreotide, a long acting somatostatin analogue, has been shown to raise IGFBP-1 plasma levels and/or hepatic mRNA in both humans and rats (Ezzat et al. 1991, Flyvbjerb et al. 1995). SRIH and its analogues may increase IGFBP-1 through its inhibitory effect upon $\mathrm{GH}$ and/or insulin. However, in humans the effect of SRIH analogues upon IGFBP-1 has been shown to be at least partly independent of these hormones (Ezzat et al. 1992, Wolthers et al. 1994). Moreover, a direct effect has been reported in human hepatoma cells (Ren et al. 1992). Interestingly, in our study, the rise in IGFBP-1 and SRIH coincided with high levels of both insulin and GH. SRIH may also have participated in the late decrease in IGF-I, in response to endotoxin, since octreotide decreases IGF-I plasma levels and/or hepatic expression in GH-treated GH-deficient humans and rats (Laursen et al. 1993,
Ambler et al. 1996). The selective blockade of somatostatin action during endotoxin challenge should be useful in order to further characterise the involvement of SRIH in septic shock pathophysiology.

In conclusion, endotoxin induced complex effects upon the IGF-I/IGFBP system in sheep. Moderately decreased IGF-I and increased IGFBP-1 plasma levels faced a sustained GH increase, suggesting that endotoxin leads to a state of resistance to $\mathrm{GH}$, which may be enhanced by reduced IGF-I bioavailability and/or action, and may participate in the pathophysiology of the catabolic state seen in sepsis. The temporal analysis of hormone responses suggests that the prolonged and substantial SRIH rise we recently described (Briard et al. 1998a), may be involved in endotoxin-induced alterations of the IGF/IGFBP system, together with glucocorticoids and cytokines as more generally assumed.

\section{Acknowledgements}

The authors express their thanks to Mr Vincent and his team (Ecole Nationale Supérieure d'Agronomie) for their help throughout the study.

\section{References}

Ambler GR, Butler AA, Padmanabhan J, Breier BH \& Gluckman PD 1996 The effects of octreotide on GH receptor and IGF-I expression in the GH-deficient rat. Journal of Endocrinology 149 223-231.

Baciuchka M, Remacle-Bonnet M, Garrouste F, Favre R, Sastre B \& Pommier M 1998 Insulin-like growth factor (IGF)-binding protein-3 (IGFBP-3) proteolysis in patients with colorectal cancer: possible association with the metastatic potential of the tumor. International Journal of Cancer 79 460-467.

Balteskard L, Unneberg K, Mjaaland M, Sager G, Jenssen TG \& Revhaug A 1998 Treatment with growth hormone and insulin-like growth factor-1 in septicemia: effects on carbohydrate metabolism. European Surgical Research 30 79-94.

Battaglia DF, Bowen JM, Krasa HB, Thrun La, Viguie C \& Karsch FJ 1997 Endotoxin inhibits the reproductive neuroendocrine axis while stimulating adrenal steroids: a simultaneous view from hypophyseal portal and peripheral blood. Endocrinology 138 4273-4281.

Bocquier F, Bonnet M, Faulconnier Y, Guerre-Millo M, Martin P \& Chilliard Y 1998 Effects of photoperiod and feeding level on perirenal adipose tissue metabolic activity and leptin synthesis in the ovariectomized ewe. Reproduction, Nutrition, Development $\mathbf{3 8}$ 489-498.

Botfield C, Ross RJ \& Hinds CJ 1997 The role of IGFs in catabolism. Baillières Clinical Endocrinology and Metabolism 11 679-697.

Briard N, Guillaume V, Frachebois C, Rico-Gomez M, Sauze N, Oliver C \& Dutour A 1998 a Endotoxin injection increases growth hormone and somatostatin secretion in sheep. Endocrinology 139 2662-2669.

Briard N, Rico-Gomez M, Guillaume V, Sauze N, Vuaroqueaux V, Dadoun F, Le Bouc Y, Oliver C \& Dutour A 1998b Hypothalamic mediated action of free fatty acid on growth hormone secretion in sheep. Endocrinology 139 4811-4819.

Brismar K, Fernqvist-Forbes E, Wahren J \& Hall K 1994 Effect of insulin on the hepatic production of insulin-like growth 
factor-binding protein-1 (IGFBP-1), IGFBP-3, and IGF-I in insulin-dependent diabetes. Journal of Clinical Endocrinology and Metabolism 79 872-878.

Chang HR \& Bistrian B 1998 The role of cytokines in the catabolic consequences of infection and injury. JPEN. Journal of Parenteral and Enteral Nutrition 22 156-166.

Cohick WS \& Clemmons DR 1993 The insulin-like growth factors. Annual Review of Physiology 55 131-153.

Cohick WS, McGuire MA, Clemmons DR \& Bauman DE 1992 Regulation of insulin-like growth factor binding proteins in serum and lymph of lactating cows by somatotropin. Endocrinology 130 1508-1514.

Coleman ES, Elsasser TH, Kemppainen RJ, Coleman DA \& Sartin JL 1993 Effect of endotoxin on pituitary hormone secretion in sheep. Neuroendocrinology 58 111-122.

Conover CA, Divertie GD \& Lee PD 1993 Cortisol increases plasma insulin-like growth factor binding protein-1 in humans. Acta Endocrinologica 128 140-143.

Cooney RN, Kimball SR \& Vary TC 1997 Regulation of skeletal muscle protein turnover during sepsis: mechanisms and mediators. Shock 7 1-16.

Dadoun F, Guillaume V, Sauze N, Farisse J, Velut JG, Orsoni JC, Gaillard R \& Oliver C 1997 Effect of endotoxin on the hypothalamus pituitary axis in sheep. European Journal of Endocrinology 138 193-197.

Dahn MS, Lange MP \& Jacobs LA 1998 Insulin-like growth factor 1 production is inhibited in human sepsis. Archives of Surgery 123 1409-1414.

Donaghy AJ \& Baxter RC 1996 Insulin-like growth factor bioactivity and its modification in growth hormone resistant states. Baillières Clinical Endocrinology and Metabolism 10 421-446.

Elin RJ, Wolff SM, McAdam KPWJ, Chedid L, Audibert F, Bernard C \& Oberling F 1981 Properties of reference Escherichia coli endotoxin and its phthalylated derivative in humans. Journal of Infectious Diseases 144 329-336.

Elsasser TH, Caperna TJ \& Rumsey TS 1995 Endotoxin administration decreases plasma insulin-like growth factor (IGF)-I and IGF-binding protein-2 in angus $\mathrm{x}$ hereford steers independent of changes in nutritional intake. Journal of Endocrinology 144 109-117.

Elson MK, Oken MM \& Schafer RB 1982 Effect of endotoxin fever on plasma clearance of thyrotropin and triiodothyronine: concise communications. Journal of Nuclear Medicine 23241.

Ezzat S, Ren SG, Braunstein GD \& Melmed S 1991 Octreotide stimulates insulin-like growth factor binding protein-1 (IGFBP-1) levels in acromegaly. Journal of Clinical Endocrinology and Metabolism 73 441-443.

Ezzat S, Ren SG, Braunstein GD \& Melmed S 1992 Octreotide stimulates insulin-like growth factor-binding protein-1: a potential pituitary-independent mechanism for drug action. Journal of Clinical Endocrinology and Metabolism 75 1459-1463.

Fan J, Molina PE, Gelato MC \& Lang CH 1994 Differential tissue regulation of insulin-like growth factor-I content and binding proteins after endotoxin. Endocrinology 134 1685-1692.

Fan J, Char D, Kolasa AJ, Pan W, Maitra SR, Patlak CS, Spolarics Z, Gelato MC \& Lang CH 1995a Alterations in hepatic production and peripheral clearance of IGF-I after endotoxin. American Journal of Physiology 269 E33-E42.

Fan J, Char D, Bagby GJ, Gelato MC \& Lang CH $1995 b$ Regulation of insulin-like growth factor-I (IGF-I) and IGF-binding proteins by tumor necrosis factor. American Journal of Physiology 269

\section{R1204-R1212.}

Fan J, Wojnar MM, Theodorakis M \& Lang CH 1996 Regulation of insulin-like growth factor (IGF)-I mRNA and peptide, and IGFbinding proteins by interleukin-1. American Journal of Physiology 270 R621-R629.
Fletcher TP, Thomas GB, Dunshea FR, Moore LG \& Clarke IJ 1995 IGF feedback effects on growth hormone secretion in ewes: evidence for action at the pituitary but not the hypothalamic level. Journal of Endocrinology 144 323-331.

Flyvbjerg A, Schuller AG, van Neck JW, Groffen C, Orskov H \& Drop SL 1995 Stimulation of hepatic insulin-like growth factorbinding protein-1 and -3 gene expression by octreotide in rats. Journal of Endocrinology 147 545-551.

Gottardis M, Benzer A, Koller W, Luger TJ, Puhringer F \& Hackl J 1991 Improvement of septic syndrome after administration of recombinant human growth hormone (rhGH)? Journal of Trauma 12 777-787.

Hardouin S, Gourmelen M, Noguiez P, Seurin D, Roghani M, Le Bouc Y, Povoa G, Merimee TJ, Hossenlopp P \& Binoux M 1989 Molecular forms of serum insulin-like growth factor (IGF) binding proteins in man: relationships with growth hormone and IGFs and physiological significance. Journal of Clinical Endocrinology and Metabolism 60 290-294.

Hevener W, Almond GW, Armstrong JD \& Richards RG 1997 Effects of acute endotoxemia on serum somatotropin and insulinlike growth factor I concentrations in prepubertal gilts. American Journal of Veterinary Research 58 1010-1013.

Hossenlopp P, Seurin D, Segovia-Quinson B, Hardouin S \& Binoux M 1986 Analysis of serum insulin-like growth factor binding protein using Western blotting: use of the method for titration of the binding proteins and competitive binding studies. Analytical Biochemistry 154 138-143.

Jenkins RC \& Ross RJ 1996 a The endocrinology of the critically ill. Current Opinion in Endocrinology and Diabetes 3 138-145.

Jenkins RC \& Ross RJ $1996 b$ Acquired growth hormone resistance in catabolic states. Baillières Clinical Endocrinology and Metabolism 10 411-419.

Jones JI \& Clemmons DR 1995 Insulin-like growth factors and their binding proteins: biological actions. Endocrine Reviews 16 3-34.

Jurasinski CV \& Vary TC 1995 Insulin-like growth factor I accelerates protein synthesis in skeletal muscle during sepsis. American Journal of Physiology 269 E977-E981.

Kasting NW \& Martin JB 1982 Altered release of growth hormone and thyrotropin induced by endotoxin in the rat. American Journal of Physiology 243 E332-E337.

Lang CH, Pollard V, Fan J, Traber LD, Traber DL, Frost RA, Gelato MC \& Prough DS 1997 Acute alterations in growth hormoneinsulin-like growth factor axis in humans injected with endotoxin. American Journal of Physiology 273 R371-R378.

Lassarre C \& Binoux M 1994 Insulin-like growth factor binding protein-3 is functionally altered in pregnancy plasma. Endocrinology 134 1254-1262.

Laursen T, Jorgensen JO, Orskov H, Moller J, Harris AG \& Christiansen JS 1993 Effects of octreotide on insulin-like growth factor I and metabolic indices in growth hormone-treated growth hormone-deficient patients. Acta Endocrinologica 129 399-408.

Lee PD, Conover CA \& Powell DR 1993 Regulation and function of insulin-like growth factor-binding protein-1. Proceedings of the Society for Experimental Biology and Medicine 204 4-29.

Lewitt MS 1994 Role of the insulin-like growth factors in the endocrine control of glucose homeostasis. Diabetes Research and Clinical Practice 23 3-15.

Li YH, Fan J \& Lang CH 1997 Differential role of glucocorticoids in mediating endotoxin-induced changes in IGF-I and IGFBP-1. American Journal of Physiology 272 R1990-R1997.

Luo J, Reid RE \& Murphy LJ 1990 Dexamethasone increases hepatic insulin-like growth factor binding protein-1 (IGFBP-1) mRNA and serum IGFBP-1 concentrations in the rat. Endocrinology 127 $1456-1462$.

McCann JP, Loo SC, Aalseth DL \& Abribat T 1997 Differential effects of GH stimulation on fasting and prandial metabolism and plasma IGFs and IGF-binding proteins in lean and obese sheep. Journal of Endocrinology 154 329-346. 
Makara GB, Stark E \& Meszaros T 1971 Corticotrophin release induced by $E$. coli endotoxin after removal of the medial hypothalamus. Endocrinology 88 412-416.

Mizock BA 1995 Alterations in carbohydrate metabolism during stress: a review of the literature. American Journal of Medicine 98 75-84.

Morrison DC \& Ryan JL 1987 Endotoxins and disease mechanisms. Annual Review of Medicine 38 417-432.

Pao CI, Farmer PK, Begovic S, Villafuerte BC, Wu GJ, Robertson DG \& Phillips LS 1993 Regulation of insulin-like growth factor-I (IGF-I) and IGF-binding protein-1 gene transcription by hormones and provision of amino acids in rat hepatocytes. Molecular Endocrinology 7 1561-1568.

Peter AT, Bosu WT \& DeDecker RJ 1989 Suppression of preovulatory luteinizing hormone surges in heifers after intrauterine infusions of Escherichia coli endotoxin. American Journal of Veterinary Research $\mathbf{5 0}$ 368-373.

Ren SG, Ezzat S, Melmed S \& Braunstein GD 1992 Somatostatin analog induces insulin-like growth factor binding protein-1 (IGFBP-1) expression in human hepatoma cells. Endocrinology 131 2479-2481.

Rivier C, Chizzonite R \& Vale W 1989 In the mouse, the activation of the hypothalamic-pituitary-adrenal axis by a lipopolysaccharide (endotoxin) is mediated through interleukin-1. Endocrinology 125 2800-2805

Samstein B, Hoimes ML, Fan J, Frost RA, Gelato MC \& Lang CH 1996 IL-6 stimulation of insulin-like growth factor binding protein (IGFBP)-1 production. Biochemical and Biophysical Research Communications 228 611-615.

Soto L, Martin AI, Millan S, Vara E \& Lopez-Calderon A 1998 Effects of endotoxin lipopolysaccharide administration on the somatotropic axis. Journal of Endocrinology 159 239-246.
Spencer GSG, Berry C, Hodgkinson SC \& Bass JJ 1993 On the neuroendocrine role of insulin-like growth factors 1 and 2 in the regulation of growth hormone secretion. Molecular and Cellular Neuroscience 4 538-542.

Thissen JP, Ketelslegers JM \& Underwood LE 1994 Nutritional regulation of the insulin-like growth factors. Endocrine Reviews $\mathbf{1 5}$ 80-101.

Thissen JP \& Verniers J 1997 Inhibition by interleukin-1 $\beta$ and tumor necrosis factor- $\alpha$ of the insulin-like growth factor I messenger ribonucleic acid response to growth hormone in rat hepatocyte primary culture. Endocrinology 138 1078-1084.

Tilders FJH, DeRijk RH, Van Dam A-M, Vincent VAM, Schotanus K \& Persoons JHA 1994 Activation of the hypothalamuspituitary-adrenal axis by bacterial endotoxins: routes and intermediate signals. Psychoneuroendocrinology 19 209-232.

Van de Berghe G, de Zegher F \& Bouillon R 1998 Acute and prolonged critical illness as different neuroendocrine paradigms. Journal of Clinical Endocrinology and Metabolism 83 1827-1834.

Voerman HJ, Strack van Schijndel RJM, Groeneveld ABJ, de Boer H, Nauta JP \& Thijs LG 1992 Pulsatile hormone secretion during severe sepsis: accuracy of different blood sampling regimens. Metabolism 41 934-940.

Wolthers T, Grofte T, Flyvbjerg A, Frystyk J, Vilstrup H, Orskov H \& Foegh M 1994 Dose-dependant stimulation of insulin-like growth factor-binding protein-1 by lanreotide, a somatostatin analog. Journal of Clinical Endocrinology and Metabolism 78 141-144.

Received 24 March 1999

Revised manuscript received 29 July1999 Accepted 20 September 1999 